\title{
Occurrence of the Accessory Foramina of the Mandibular Ramus in Brazilian Adults and its Relation to Important Mandibular Landmarks
}

\author{
Presencia de Forámenes Accesorios de la Rama Mandibular en Adultos Brasileños \\ y su Relación con Importantes Puntos de Referencia de la Anatomía Mandibular
}

Lima, F. J. C.."; Oliveira Neto, O. B. ${ }^{* *}$; Barbosa, F. T. ${ }^{* * *}$; Dantas, L. C. S. ${ }^{* * * *}$; Olave, E.***** \& Sousa-Rodrigues, C. F. ${ }^{* * * * * *}$

LIMA, F. J. C.; OLIVEIRA NETO, O. B.; BARBOSA, F. T.; DANTAS, L. C. S.; OLAVE, E. \& SOUSA-RODRIGUES, C. F. Occurrence of the accessory foramina of the mandibular ramus in Brazilian adults and its relation to important mandibular landmarks. Int. J. Morphol., 34(1):330-334, 2016.

SUMMARY: The presence of the Accessory Foramina of the Mandibular Ramus (AFMR) may be related to anaesthetic failures in the inferior alveolar nerve block and complications in the ramus surgeries. The purpose of the present investigation was to determine the occurrence of the AFMR in adults and, when present, measure its distance to the Mandibular Foramen (MF), to the Mandibular Lingula (ML) and to the posterior margin of the mandibular ramus (PM), comparing data obtained in both sides of the mandible. Thirty dry human mandibles were selected to the present study. The AFMR was considered as every foramina identified between the MF and the PM. When present, its distance to the MF, to the ML and to the PM was measured. The AFMR was identified in 15 of the 30 examined mandibles $(50 \%)$, presenting exclusively on the right side in four cases $(13.33 \%)$, exclusively on the left side in other four cases $(13.33 \%)$ and simultaneously on both mandibular antimeres in seven of the 30 inspected mandibles (23.33\%). The AFMR is a structure considered as anatomic vari4ation but it was present in one of each two mandibles investigated, with the same occurrence in both mandibular sides. For the cases of occurrence of the AFMR, the professional will be able to locate it in a central position between the MF and the PM, distant about seven millimeters to the MF and $10.50 \mathrm{~mm}$ to the ML in both sides of the mandible.

KEY WORDS: Mandible; Mandibular landmarks; Accessory foramina; Anatomical variation.

\section{INTRODUCTION}

Anaesthetic failures in the inferior alveolar nerve block may be related to several anatomic variations in the mandible and its landmarks as well as in the inferior alveolar nerve and its branches. These alterations in normality are often related (Carter \& Keen, 1971; Langlais et al., 1985; Melamed, 2004; Auluck et al, 2007; Monazzi et al., 2011).

Between the aforementioned structures, the presence of the Accessory Foramina of the Mandibular Ramus (AFMR) has aroused particular interest of researches around the world, especially due to the lack of consensus regarding its occurrence, positioning, number, content, nomenclature and possible clinical implications (Suazo Galdames et al., 2009; Przstanska \& Bruska, 2010; Freire et al., 2012; Samanta \& Kharb, 2013).

The presence of the AFMR may be related to anaesthetic failures in the afferent block of the inferior alveolar nerve when anatomic variations of this nerve pass through this foramina and provide accessory innervation to the inferior teeth (Kaufman et al., 2000). A fact that supports such theory advocates an embryologic premise, where the ossification of the mandibular canal takes place around the inferior alveolar nerve; hence, if this nerve presents

\footnotetext{
Profesor de Anatomia Descriptiva y Topográfica de la Universidade Federal de Alagoas, Programa de Pós-Graduação em Ciências da Saúde (Doutorado), Universidade Federal de Alagoas, Maceió, Brasil.

** Estudiante de Odontologia, Universidade Federal de Alagoas, Maceió, Brasil.

*** $\quad$ Profesor de Anestesiología, Doctor, Universidade Federal de Alagoas, Maceió, Brasil.

***** Programa de Pós-Graduação em Ciências da Saúde (Mestrado), Universidade Federal de Alagoas, Maceió, Brasil.

****** Facultad de Medicina, Universidad de La Frontera, Temuco, Chile.

******* Profesor de Anatomia Descritiva y Topográfica, Doctor, Universidade Federal de Alagoas y Universidade Estadual de Ciências da Saúde de Alagoas, Maceió, Brasil.
} 
variations, the mandibular canal will also present and may open posteriorly in accessory foramens or foraminas in the mandibular ramus (Ten Cate, 1998; Lipski et al., 2013).

However, in mandibles of newborns, the scientific literature reports the identification of the AFMR in $100 \%$ of the studied cases (Suazo Galdames et al.) as the posterior opening of an accessory mandibular canal - the Conduct of Serres (CS) - which is present during the mandibular development and in the temporary teeth phase, where it provides passage to a vein, the vein of Serres (Figún \& Garino, 2001), which drains blood of the inferior teeth in a accessory manner (Rouvière \& Delmas, 2005; Freire et al.; Lipski et al.; Samanta \& Kharb). The CS and its content may persist in the adult with presence varying between 16.6 $\%$ (Freire et al.) and $42.6 \%$ (Suazo Galdames et al.).

Despite the existence of studies about the identification of the AFMR in adults, does not exist, to this moment, scientific reference values that allows one to locate the AFMR in relation to the Mandibular Foramen (MF) and the Mandibular Lingula (ML) - strategic anatomic landmarks that must be considered when the inferior alveolar nerve block or surgical procedures in the mandibular ramus are necessary (Malamed; Trauner \& Obgeser, 1957a, 1957b). Therefore, the purpose of the present investigation was to determinate the occurrence of the AFMR in adults and, when present, measure its distance to the MF, to the ML and to the posterior margin of the mandibular ramus, comparing data obtained in both sides of the mandible.

\section{MATERIAL AND METHOD}

In conformity with the Brazilian Federal Law 8.501 of November 30, 1992, and after institutional approval, 30 dry human mandibles were selected to the present study. All mandibles pertained to the collection of the Human Anatomy Sector (Federal University of Alagoas, Maceió - AL, Brazil) and belonged to individuals that had already completed their permanent teeth eruption phase, even if the teeth were absent. Hemimandibles and mandibles with bone loss in the mandibular foramen and its vicinities did not participate of the scientific investigation.

The medial aspect of the mandibular ramus was inspected in both mandibular antimeres of the selected mandibles by a single examiner, which considered as AFMR every foramina found between the MF and the posterior margin of the ramus (Fig. 1), as suggested by Lipski et al. When present, the following distances were measured (Fig. 2):

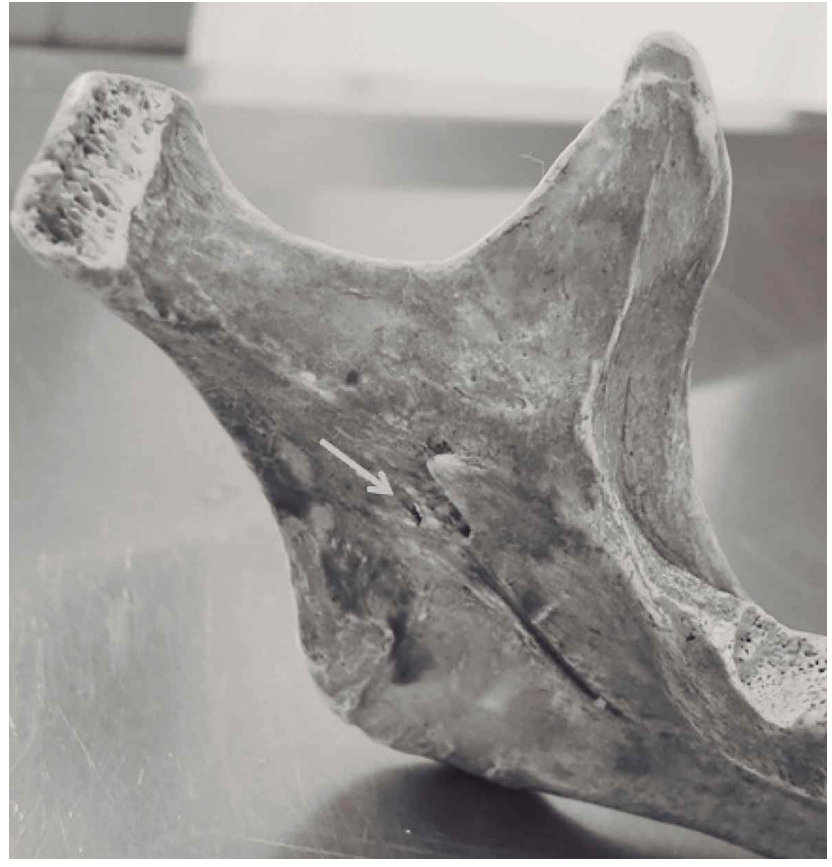

Fig. 1. Medial aspect of the mandibular ramus. The arrow indicates the AFMR.

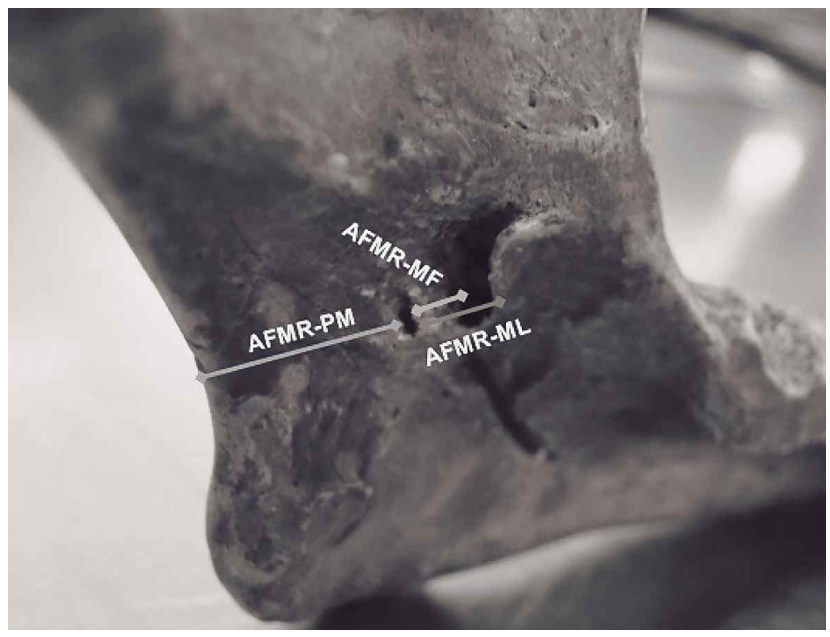

Fig. 2. Medial aspect of the mandibular ramus. AFMR-PM, AFMRMF e AFMR-ML represent, respectively, the distances between the accessory foramina of the mandibular ramus and the posterior margin of the ramus, the mandibular foramen and the mandibular lingula.

- AFMR to the posterior margin of the mandibular foramen (AFMR-MF);

- AFMR to the Mandibular Lingula (AFMR-ML);

- AFMR to the posterior margin of the ramus of the mandible (AFMR-PM).

All measures were performed with the assistance of a digital calliper (Titan TIT-C454). 
Statistical Analysis. The presence of the AFMR was presented in percentage and absolute values. The biometric data was shown by mean, standard deviation and minimum and maximum values obtained. To analyse the normality of the collected data, the Shapiro-Wilk test was executed and showed normal distribution for all analysed outcomes. Hence, the Paired Student's t Test was performed aiming to compare the anatomic positioning of the investigated structures in both sides of the mandible. Both tests were processed in the GraphPad Prism 6.0 software and the level of significance of this research was established at $5 \%$.

\section{RESULTS}

The average distances of the quantified parameters and its respective standard-deviations are shown in Table I. Here the minimum and maximum values obtained in both sides of the mandibles for each measured outcome are presented as well as its means, standard deviations and values of $\mathrm{P}$ of the normality test (Shapiro Wilk).
The AFMR was identified in 15 of the 30 examined mandibles (50\%), presenting exclusively in the right side in four cases $(13.33 \%)$, exclusively in the left side in other four cases $(13.33 \%)$ and simultaneously in both mandibular antimeres in seven of the 30 inspected mandibles $(23.33 \%)$. The AFMR was present unitarily in all occurrences.

Using the Paired Student's t Test, it was observed that the researched outcomes did not presented statistical significance $(\mathrm{P}>0.05)$ when compared in the both sides of the mandible, as available in Table II.

Table I. Values related to the measured outcomes in both sides of the mandible.

\begin{tabular}{lccccc}
\hline Parameters & Mean & SD & Minimum & Maximum & Value of P \\
\hline RAFMR-MF & 6.90 & \pm 2.03 & 3.60 & 12.00 & 0.053 \\
LAFMR-MF & 7.15 & \pm 2.51 & 4.40 & 12.70 & 0.234 \\
RAFMR-ML & 10.49 & \pm 2.52 & 7.10 & 16.80 & 0.065 \\
LAFMR-ML & 10.31 & \pm 2.85 & 7.40 & 16.00 & 0.161 \\
RAFMR-PM & 7.85 & \pm 2.76 & 1.80 & 11.70 & 0.400 \\
LAFMR-PM & 8.52 & \pm 3.68 & 0.80 & 10.70 & 0.132 \\
\hline
\end{tabular}

RAFMR= Right Accessory Foramina of the Mandibular Ramus; LAFMR= Left Accessory Foramina of the Mandibular Ramus; MF= Mandibular Foramen; ML= Mandibular Lingula; PM= Posterior Margin of the Mandibular Ramus; $\mathrm{SD}=$ Standard Deviation. The values of P were obtained using the Shapiro Wilk's normality test, which indicated normal distribution for all outcomes $(\mathrm{P}>0.05)$.

\section{DISCUSSION}

The Accessory Foramina of the Mandibular Ramus represents the posterior opening of the Conduct of Serres, which was described by the first time in 1817 , according to Suazo Galdames et al. Its content is uncertain - it may provide passage to a branch of the inferior alveolar nerve before its passage through the MF or to a persistent vein that used to drain blood from the inferior teeth during the temporary teeth eruption phase and it is not obliterated with the CS (Figún \& Garino; Rouvière \& Delmas).
Table II. Values of P obtained for each compared outcome using the Paired Student's t Test.

\begin{tabular}{lc}
\hline & Value of $\mathbf{P}$ \\
\hline AFMR-MF & 0.900 \\
AFMR-ML & 0.302 \\
AFMR-PM & 0.297 \\
\hline
\end{tabular}

None of them presented statistical significance $(\mathrm{P}>0.05)$. 
studied by us or to a foramina adjacent to the lingual foramen (Przstanska \& Bruska, 2010, 2012). The term "Conduct of Serres" has also been used (Sanchis et al., 2003). We corroborate with Suazo Galdames et al., by claiming that the names of the anatomic structures must indicate its location, form and function. Therefore, the eponym "Conduct of Serres" must be deleted. Nevertheless, we disagree with the same author when he suggested to call the mentioned structure "Paramandibular Foramen", considering that the structure studied by us was way smaller than a standard sized foramen and the term "Paramandibular" does not specify the precise location of the foramina - it may refer to the MF as well as the mandible in general. Thus, taking into account the confusion and the lack of consensus regarding the nomenclature of the structure in check, we suggest that the term "Accessory Foramina of the Mandibular Ramus" be the reference standard for future studies about this structure.

Suazo Galdames et al. and Freire et al. researched the incidence of the AFMR in Brazilians dry mandibles. In the first study, the AFMR was present posteriorly to the MF bilaterally in $19.1 \%$ of the cases and unilaterally in $23.4 \%$ of the occasions. The second study identified the AFMR positioned above the MF in $43.2 \%$ of cases and inferiorly to the MF in $27.9 \%$ of occasions. Samanta et al., found the AFMR in 10 of the 60 studied mandibles (16.6\%), without specifying its location in the medial aspect of the ramus. Our study considered as AFMR any foramina identified in the medial aspect of the mandibular ramus, posteriorly to the MF and anteriorly to the PM of the ramus (Suazo Galdames et al.; Lipski et al.). The AFMR was present in at least one mandibular ramus in $50 \%$ of the examined mandibles. The high occurrence of this foramina became clear, not only in our investigation, but in the aforementioned studies as well. For comparative purposes, the percentage data obtained in other scientific investigations and in our own are available in Table III.

The presence of the AFMR may be one of the causes of anaesthetic failure in the inferior alveolar nerve block (Kaufman et al.), may cause complications during orthognathic and corrective surgeries in the mandibular ramus (Sanchis et al.) and, just like other foraminas in the mandible (Haveman \& Tebo, 1976), may become a pathway to neoplasic cell proliferation in the trabecular bone of the mandible (Fannibunda \& Matthews, 1999). For the cases of failures of the inferior alveolar nerve block when the AFMR is present, we recommend the use of a higher anaesthetic technique - the Gow-Gates Block (Gow-Gates, 1973) which advocates the deposition of the anaesthetic solution in the vicinities of the oval foramen, at the emergence of the mandibular nerve in the infratemporal fossa. Thus, the professional will be able to anesthetise all of the afferent branches of the inferior alveolar nerve even in the presence of anatomic variations (Meechan, 1999).

Analyzing the positioning of the AFMR and considering the standard deviation, this structure was situated in a central position between the MF and the PM in both sides of the mandible. The distance AFMR-MF corresponded to approximately two thirds of the distance AFMR-ML in both mandibular antimeres.

To this moment, the data mentioned in the last paragraph and detailed in Table I, is not presented in any other study in the field. The next step will be to investigate the occurrence and positioning of the AFMR in relation to mandibular landmarks in vivo and in vitro using imaging exams.

The data presented in this study showed the occurrence of a structure considered as anatomic variation but that it was present in one of each of two mandibles investigated, with the same occurrence in both mandibular sides. For the cases of occurrence of the AFMR, the professional will be able to locate it in a central position between the MF and the PM, distant about $7.0 \mathrm{~mm}$ to the $\mathrm{MF}$ and $10.50 \mathrm{~mm}$ to the ML in both sides of the mandible.

\section{ACKNOWLEDGEMENTS}

We acknowledge the assistance that was provided to us by Mr. Antônio Alves da Silva, lab technician of the Federal University of Alagoas. We also acknowledge the unconditional support and incentive by all members of the Research Group “Applied Morphology and Health” (CNPq).

Table III. Comparison between previous studies and our own.

\begin{tabular}{lcccc}
\hline Authors & $\begin{array}{c}\text { Unilateral } \\
\text { occurrence }\end{array}$ & $\begin{array}{c}\text { Bilateral } \\
\text { occurrence }\end{array}$ & $\begin{array}{c}\text { Total } \\
\text { occurrence }\end{array}$ & $\begin{array}{c}\text { Location of the } \\
\text { AFMR }\end{array}$ \\
\hline Suazo Galdames et al. (2009) & $23.4 \%$ & $19.1 \%$ & $426 \%$ & Posteriorly to the MF \\
Freire et al. (2012) & $25.2 \%$ & $18.0 \%$ & $43.2 \%$ & Superiorly the MF \\
Freire et al. (2012) & $22.0 \%$ & $5.8 \%$ & $27.9 \%$ & Inferiorly the MF \\
Samanta et al. $(2013)$ & --- & --- & $16.6 \%$ & --- \\
Our Study & $26.6 \%$ & $23.3 \%$ & $50.0 \%$ & Posteriorly to the MF \\
\hline
\end{tabular}

Accessory Foramina of the Mandibular Ramus (AFMR). MF= Mandibular Foramen. 
LIMA, F. J. C.; OLIVEIRA NETO, O. B.; BARBOSA, F. T.; DANTAS, L. C. S.; OLAVE, E. \& SOUSA-RODRIGUES, C. F. Presencia de forámenes accesorios de la rama mandibular en adultos brasileños y su relación con importantes puntos de referencia de la anatomía mandibular. Int. J. Morphol., 34(1):330-334, 2016.

RESUMEN: La presencia de forámenes accesorios de la rama mandibular (FARM) puede estar relacionada con fallas que ocurren en el bloqueo anestésico del nervio alveolar inferior y con complicaciones durante cirugías de la rama mandibular. El propósito del presente estudio fue determinar la presencia de FARM en adultos brasileños y cuando éstos estuvieren presentes, medir la distancia al foramen mandibular (FM), a la língula de la mandíbula (LM) y al margen posterior de la rama mandibular (MP), comparando estos datos en ambos lados de la mandíbula. Para ello fueron seleccionadas 30 mandíbulas humanas secas. El FARM fue considerado como cada foramen identificado entre el FM y MP. El FARM fue identificado en 15 de las 30 mandíbulas examinadas (50\%), presentándose en el lado derecho en 4 casos (13,33\%), en el lado izquierdo en 4 (13,33 $\%)$ y en ambos lados en 7 (23,33\%). Los FARM son considerados como una variación anatómica pero en este estudio estuvo presente en una de cada dos mandíbulas, con la misma frecuencia en ambas mandíbulas. En el caso de presencia del FARM, el profesional será capaz de identificarlo en una posición central entre el FM y el MP, distante $7 \mathrm{~mm}$ aproximadamente del FM y a 10,5 mm de la LM en ambos lados de la mandíbula.

PALABRAS ClAVE: Mandíbula; Puntos de referencia mandibular; Forámenes accesorios; Variación anatómica.

\section{REFERENCES}

Auluck, A.; Pai, K. M. \& Mupparapu, M. Multiple mandibular nerve canals: radiographic observations and clinical relevance. Report of 6 cases. Quintessence Int., 38(9):781-7, 2007.

Carter, R. B. \& Keen, E. N. The intramandibular course of the inferior alveolar nerve. J. Anat., 108(Pt. 3):433-40, 1971.

Fanibunda, K. \& Matthews, J. N. Relationship between accessory foramina and tumour spread in the lateral mandibular surface. J. Anat., 195(Pt. 2):185-90, 1999.

Figún, M. \& Garino, R. Anatomia Odontológica Funcional y Aplicada. 2a ed. Buenos Aires, El Ateneo, 2001.

Freire, A. R.; Rossi, A. C.; Prado, F. B; Caria, P. H. F. \& Botacin, P. R. Incidence of the mandibular accessory foramina in Brazilian population. J. Morphol. Sci., 29(3):171-3, 2012.

Gow-Gates, G. A. Mandibular conduction anesthesia: a new technique using extraoral landmarks. Oral Surg. Oral Med. Oral Pathol., 36(3):321-8, 1973.

Haveman, C. W. \& Tebo, H. G. Posterior accessory foramina of the human mandible. J. Prosthet. Dent., 35(4):462-8, 1976.

Kaufman, E.; Serman, N. J. \& Wang, P. D. Bilateral mandibular accessory foramina and canals: a case report and review of the literature. Dentomaxillofac. Radiol., 29(3):170-5, 2000.

Langlais, R. P.; Broadus, R. \& Glass, B. J. Bifid mandibular canals in panoramic radiographs. J. Am. Dent. Assoc., 110(6):923-6, 1985.

Lipski, M.; Tomaszewska, I. M.; Lipska, W.; Lis, G. J. \& Tomaszewski, K. A. The mandible and its foramen: anatomy, anthropology, embryology and resulting clinical implications. Folia Morphol. (Warsz.), 72(4):285-92, 2013.

Malamed, S. F. Manual de Anestesia Local. $5^{\text {a }}$ ed. Rio de Janeiro, Guanabara Koogan, 2004.

Meechan, J. G. How to overcome failed local anaesthesia. Br. Dent. J., 186(1):15-20, 1999.

Monnazzi, M. S.; Passeri, L. A.; Gabrielli, M. F. R.; Bolini, P. D. A.; de Carvalho, W. R. S. \& da Costa Machado, H. Anatomic study of the mandibular foramen, lingula and antilingula in dry mandibles, and its statistical relationship between the true lingula and the antilingula. Int. J. Oral Maxillofac. Surg., 41(1):74-8, 2012

Przystanska, A. \& Bruska, M. Accessory mandibular foramina: histological and immunohistochemical studies of their contents. Arch. Oral Biol., $55(1): 77-80,2010$.

Przystanska, A. \& Bruska, M. Anatomical classification of accessory foramina in human mandibles of adults, infants, and fetuses. Anat. Sci. Int., 87(3):141-9, 2012.

Samanta, P. P. \& Kharb, P. Morphometric analysis of mandibular foramen and incidence of accessory mandibular foramina in adult human mandibles of an indian population. Rev. Argent. Anat. Clin., 5(2):60-6, 2013.

Sanchis, J. M.; Peñarrocha, M. \& Soler, F. Bifid mandibular canal. J. Oral Maxillofac. Surg., 61(4):422-4, 2003.

Suazo Galdames, I. C.; Zavando Matamala, D. A. \& Smith, R. L. s the Conduct of Serres an Anatomical Variation in Adults? Int. J. Morphol., 27(1):437, 2009.

Rouvière, H. \& Delmas, A. Anatomía Humana: Descriptiva, Topográfica y Funcional. $11^{\mathrm{a}}$ ed. Madrid, Elsevier, 2005.

Ten Cate, A. R. Oral Histology: Development, Structure, and Function. 5a ed. St. Louis, Mosby, 1998.

Trauner, R. \& Obwegeser, H. The surgical correction of mandibular prognathism and retrognathia with consideration of genioplasty. I. Surgical procedures to correct mandibular prognathism and reshaping of the chin. Oral Surg. Oral Med. Oral Pathol., 10(7):677-89, 1957a.

Trauner, R. \& Obwegeser, H. The surgical correction of mandibular prognathism and retrognathia with consideration of genioplasty. II. Operating methods for microgenia and distoclusion. Oral Surg. Oral Med. Oral Pathol., 10(9):787-92, 1957b.

\section{Correspondence to:}

Célio Fernando de Sousa-Rodrigues. PhD.

Sector of Human Anatomy

Universidade Estadual de Ciências da Saúde de Alagoas

Rua Dr. Jorge de Lima, 113

Trapiche da Barra, CEP.: 57010-300,

Maceió - Al.

BRAZIL

Email: celiofernando@yahoo.com.br

Received: 08-09-2015

Accepted: 22-12-2015 